\title{
Pemanfaatan Jquery Mobile Untuk Merancang Aplikasi Kinerja Salesman
}

\section{JQuery Mobile Use for Designing Salesman Performance Application}

\author{
Gusti Syarifudin', I Dewa Ayu Eka Yuliani $^{2}$ \\ Sekolah Tinggi Manajemen Informatika dan Komputer Pontianak \\ Jl. Merdeka No. 372 Pontianak, Kalimantan Barat \\ Telp (0561) 735555, Fax (0561) 737777 \\ 1'gus_wet@yahoo.co.id, ${ }^{2}$ dewaayu.ekayuliani@gmail.com
}

\begin{abstract}
Abstrak
Penelitian ini bertujuan untuk membangun aplikasi kinerja salesman yang menggunakan mobile device dengan framework JQuery mobile yang mempermudah proses pencatatan orderan, pengecekan stok dan mengontrol sistem kinerja salesman. Penelitian ini, menggunakan metode research and development sebagai bentuk penelitian. Teknik pengumpulan data yang digunakan dalam penelitian ini adalah wawancara, observasi, serta studi dokumentasi. Pemodelan sistem menggunakan unified modeling language, sedangkan metode perancangan aplikasi menggunakan agile software development method dengan pendekatan extreme programming. Untuk membangun web mobile menggunakan bahasa pemrograman PHP (hypertext preprocessor) dengan framework JQuery mobile dan database MySQL. Penelitian ini menghasilkan fitur login salesman, fitur indent, fitur pengontrol kinerja salesman dan menampilkan laporan penjualan secara periode tertentu yang dapat diakses dari perangkat mobile salesman.
\end{abstract}

Kata kunci-Web Mobile, jQuery Mobile, Extreme Programming, Aplikasi Kinerja Salesman.

\begin{abstract}
The research aims to build a salesman performance application uses mobile device and JQuery mobile framework that simplify the process of recording orders, checking stock and control salesman performance system. Design of salesman performance application using research and development method, and techniques of data collection using interviews, observation, and documentation study. Modeling system uses unified modeling language, and extreme programming as approach of analysis and systems development that being part of agile development methods. Mobile web application build with PHP (hypertext preprocessor) and JQuery mobile framework as programming language, and using a MySQL database. The result of this research are login feature salesman, indent feature, the controller features the performance of salesmen and display sales reports in a certain period that can be accessed from a mobile device.
\end{abstract}

Keywords-Web Mobile, jQuery Mobile, Extreme Programming, Salesman Performance Application.

\section{PENDAHULUAN}

Beragamnya aplikasi yang berkembang pada saat ini memberikan pilihan dalam peningkatan kinerja suatu pekerjaan, baik yang berbasis desktop, berbasis web hingga yang sekarang ini muncul aplikasi-aplikasi baru yang berjalan dalam mobile device. Sistem informasi 
telah berkembang menjadi sistem informasi yang berbasis mobileyangdiharapkan mampu menunjang kebutuhan dalam menjalankan proses bisnis sehingga dapat meningkatkan pelayanan terhadap pelanggan dengan memberikan informasi yang lengkap mengenai produk dari sebuah perusahaan.

Aplikasi mobile memungkinkan pengguna untuk menggunakan teknologi informasi tanpa terikat ke satu lokasi, menyediakan pengguna dengan fleksibilitas, aksesibilitas dan kemudahan penggunaantelah menjadikan perangkat mobile sebagai pilihan dalam mengakses informasi [1].Untuk membangun sebuah web mobile yang terlihat dan berperilaku seperti aplikasi asli dan dapat secara otomatis bisa sesuai dengan berbagai resolusi dari perangkat, membutuhkan banyak pekerjaan jika mulai dari awal. Untuk mempercepat pengembangan, perlu didasarkan pada sebuah framework yaitu JQuery Mobile framework [2].

JQuery mobile dapat mengembangkan berbagai solusi mobile yang bekerja dengan baik di berbagai piranti sistem operasi mobile, contoh piranti yang didukung seperti: android,blackberry OS6, Fennec (Mozilla), WebOS dari HP (Palm), iOS (iPhone, iPod Touch dan I Pad), serta Opera Mobile. Penggunaan JQuery dapat memudahkan dalam pengembangan sebuah web karena JQuery menggunakan javascript library yang cepat dan ringan untuk menangani dokumen HTML, menangani event, membuat animasi dan interakasi AJAX. JQuery telah mengubah cara penulisan javascript dikarenakan JQuery dirancang untuk memperingkas kodekode javascript dengan fitur-fitur yang juga telah menggantikan teknologi flash seperti slider, photo slideshow, ataupun modal dialog.

Kinerja seorang sangat penting di dalam sebuah perusahaan terutama dalam melayani pelanggannya, seperti kasus yang terjadi pada perusahaan distributor yang bergerak dibidang penjualan bahan-bahan bangunan dan instalasi listrik yaitu PT. Papasari.PT. Papasari memerlukan sebuah sistem yang dapat membantu salesman dalam melayani pelanggan yang pada kesehariannya, salesman melakukan kunjungan kesetiap toko pelanggan untuk menawarkan produk-produk yang dijual oleh papasari.Proses pemenuhan orderan pelanggan pada PT. Papasari dilakukan oleh salesmandengan mencatat setiap pesanan pelanggan kedalam sebuah buku, yang

kemudian akan diberikan kepada marketing untuk pencatatan administrasi penjualannya.Terkadang, salesman melakukan setiap pencatatan orderan tanpa mengetahui jumlah stock sebenarnya yang ada digudang, sementara bagian gudang tidak menerima informasi orderan secara cepat sehingga orderan pelanggan baru akan diantar jika salesman sudah memberikan orderan yang dicatat tadi kebagian marketing, sehingga masih terdapat keluhan dari pelanggan tentang keterlambatan dalam proses pengantaran barang yang dapat menjadi nilai minus bagi pelayanan yang diberikan oleh PT. Papasari.

Permasalahan seperti yang telah diutarakan diatas sebenarnya bisa terpecahkan dengan menerapkan teknologi informasi yang tepat.Penelitian ini akanmenghasilkan sebuah aplikasi penjualan untuk meningkatkan kinerja salesman dengan memanfaatkan JQuery Mobile sebagai tampilan interfacenya. Kehadiran sistem ini akan bermanfaat bagi salesman untuk mencatat orderan pelanggan dengan mengunakan mobile device sebagai medianya serta dapat meningkatkan kinerja salesman dalam memenuhi setiap permintaan pelanggan.

\section{METODE PENELITIAN}

Penelitian ini menggunakan bentuk studi kasus dengan mengamati dan mempelajari secara langsung terhadap objek yang diteliti yaitu PT.Papasari Pontianak, dan dilakukan dengan menggunakan metode penelitian dan pengembangan (Research and Development), dimana metode penelitian Research and Development (R\&D) bertujuan untuk dapat menghasilkan produk tertentu digunakan penelitian yang bersifat analisis kebutuhan dan untuk menguji keefektifan produk tersebut supaya dapat berfungsi di masyarakat luas, maka diperlukan penelitian untuk menguji keefektifan produk tersebut dan output dari penelitian ini yang berupa aplikasi kinerja salesman pada PT.Papasari Pontianak [3].Perancangan aplikasi kinerja salesman berbasis JQuery menggunakan metode extreme programming (XP) yang merupakan salah satu model dari metode agile software development. Extreme programming terdiri dari planning, design, coding dan testing, metode ini melibatkan pengguna dalam pengembangan perangkat 
lunak yang dikerjakan oleh pengembang, sehingga pengguna dapat memberikan umpan balik secara terus-menerus dan komunikasi antara pengguna dengan pihak pengembang menjadi efisien [4].

Pemodelan dari aplikasi kinerja salesman menggunakan Unified Modelling Language, yang meliputi 4 (empat) diagram yaitu use case diagram, activity diagram, sequence diagram, dan class diagram. Web server mengunakan apache, bahasa pemrograman menggunakan script PHP dengan database MySQL.

\section{HASIL DAN PEMBAHASAN}

Pada penelitian ini, metode analisis dan perancangan yang digunakan adalah metode Agile Development dengan pendekatan Extreme Programming (XP).Extreme Programming mempunyai nilai-nilai dasar dalam pengembangan perangkat lunak, yaitu komunikasi, kesederhanaan, umpan balik, keberanian, dan rasa hormat.Extreme Programming mempunyai 4 tahapan yaitu planning, design, coding dan testing [4].

Pada fase planning, lebih berorientasi kepada analisa sistem yang didalamnya berisikan analisa atas kebutuhan pengguna sistem. Oleh karena itu perlu kegiatan wawancara kepada pihak PT.Papasari Pontianak untuk mengetahui kebutuhan dan fitur apa saja yang dibutuhkan dalam pengembangan sistem kinerja salesman ini. Selain wawancara, kegiatan observasi langsung juga diperlukan untuk melihat sistem yang berjalan pada PT.Papasari Pontianak.Untuk mendapatkan data yang mendukung dalam pengembangan sistem kinerja salesman ini, dilakukan studi dokumentasi dengan mempelajari dokumen, laporan serta data yang berhubungan dengan PT.Papasari Pontianak.

Kegiatan analisa diatas yang sudah dilakukan sesuai dengan kebutuhan, maka dapat dijabarkan beberapa permasalahan yang terjadi pada PT.Papasari Pontianak antara lain adalah kegiatan dalam proses pengorderan oleh salesman yang masih kurang efektif dan efisien dikarenakan masih menggunakan media tulis untuk mencatat setiap orderan pelanggan serta masih harus selalu membawa katalog produk dan list harga sehingga menimbulkan biaya tambahan untuk mencetak buku orderan, katalog produk, dan list harga yang selalu berubah-ubah. Sering pula terjadi kesalahan dalam penindaklanjutan orderan salesman pada bagian marketing, sehingga dalam proses pemenuhan kebutuhan pelanggan akan barang-barang yang tidak selalu ada stock sering terjadi kesalahan karena bagian marketing lupa barang yang sudah diorder tapi belum diproses. Setelah mengetahui berbagai permasalahan yang dihadapi maka selanjutnya akan difokuskan pada penentuan kebutuhan untuk memecahkan masalah yang ada. Dari hasil analisis kebutuhan yang dilakukanmaka diperoleh hasil berupa kebutuhan user yang dikelompokkan kedalam dua jenis kebutuhan yaitu kebutuhan fungsional dan kebutuhan non fungsional. Kebutuhan fungsional adalah kebutuhan yang berisi proses-proses apa saja yang nantinya dilakukan oleh aplikasi, untuk aplikasi kinerja salesman dibagi menjadi tiga bagian yaitu kebutuhan pemilik yang mengharpkan aplikasi mampu menampilkan data laporan transaksi harian, bulanan, tahunan dan pembayaran dari konsumen, serta dapat menampilkan informasi stok barang beserta harga. Salesman mengharapkan aplikasi dapat mempermudah dalam proses pencatatan orderan pelanggan, memperoleh informasi tentang ketersediaan barang, memudahkan dalam proses pemenuhan kebutuhan pelanggan. Marketing berharap aplikasi mampu menampilkan pesanan konsumen, dapat memproses orderan salesman dengan lebih cepat, mampu mengelola data barang, toko, pelanggan dan penjualan secara baik. Setelah mendeskripsikan kebutuhan fungsional, maka langkah selanjutnya adalah mendeskripsikan apa saja yang kebutuhan dari non-fungsional, adapun yang menjadi kebutuhan non-fungsional dari aplikasi kinerja salesman antara lain yaitu bahasa pemrograman yang digunakan adalah PHP dan javascript dengan database MySQL, serta beberapa tools antara lain Adobe Dreamweaver CS6, XAMPP 3.2, PHPMyAdmin, dan web browser yang mendukung tampilan JQuery.

Tahap design merupakan tahapan kedua dari Extreme Programming dimana pada tahap ini digunakan untuk mengubah kebutuhan pada saat tahapan planning menjadi representasi ke dalam bentuk desain. Desain yang akan dibuat yaitu perancangan arsitektur sistem, perancangan 
sistem usulan web mobile dengan menggunakan perancangan Use Case Diagram, Sequence Diagram, Activity Diagram dan Class Diagram.Arsitektur web mobile yang digunakan pada PT.Papasari Pontianak menggunakan arsitektur client/server (Gambar 1).

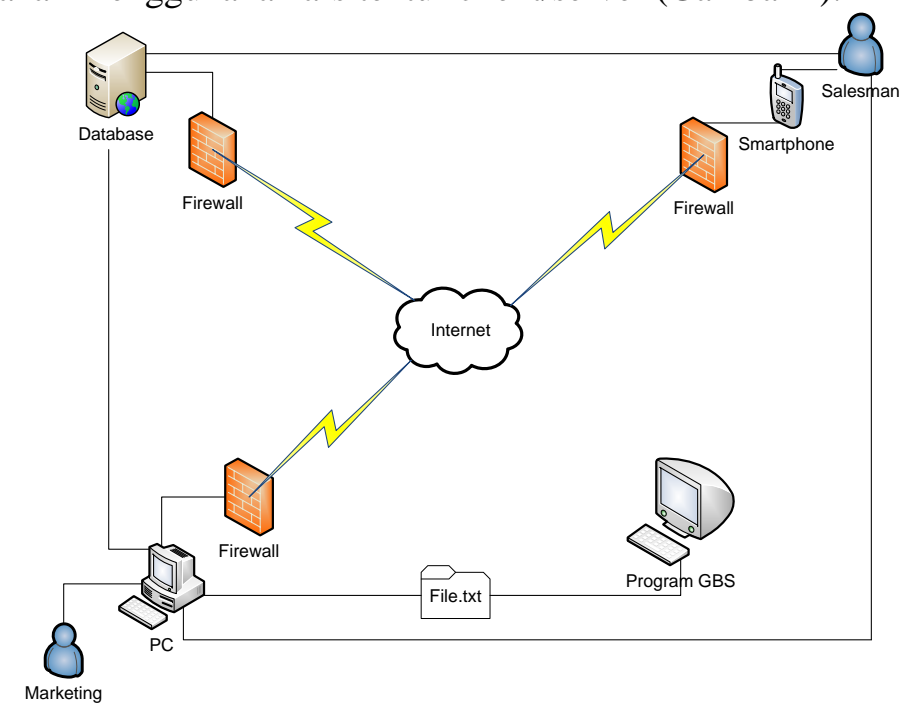

Gambar 1.Desain Arsitektur Web Mobile PT. Papasari Pontianak

Use case diagram berfungsi untuk menjelaskan manfaat dan fungsionalitas suatu sistem yang akan dirancang. Gambar 2 memperlihatkan bahwa seorang salesman yang telah melakukan login ke halaman sales akan memiliki hak untuk mencatat orderan pelanggan, melihat report, dan mencatat orderan indent dari pelanggan. Sedangkan marketing ketika telah melakukan login ke halaman marketing dapat mengelolah orderan salesman, mengelolah report, menginput data pelanggan baru, menginput data produk baru serta mengelolah orderan indent pelanggan.Pemimpin perusahaan disini dapat melihat laporan penjualan salesman sehingga dapat terus memantau kinerja salesman.

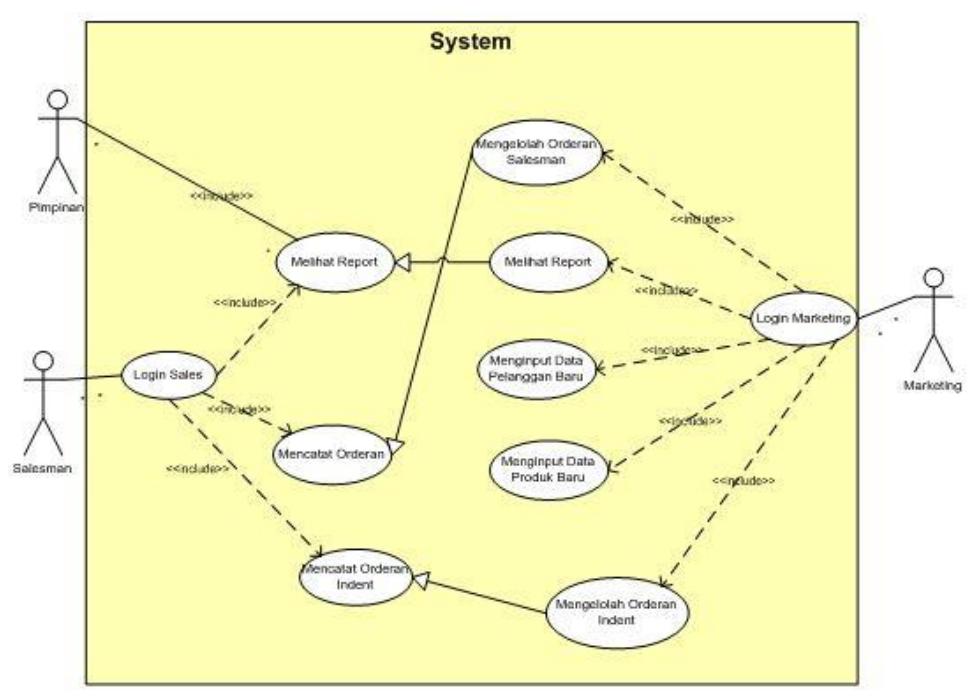

Gambar 2.Use Case Diagram Aplikasi Kinerja Karyawan

Sequence Diagram digunakan untuk menggambarkan skenario atau rangkaian langkahlangkah yang dilakukan sebagai suatu respon dari kejadian untuk menghasilkan output tertentu.Marketing yang telah login dapat melakukan penambahan akun marketing baru.marketing mengakses halaman utama home marketing dan memilih client, kemudian sistem 
akan menampilkan form data marketing dan penambahan marketing baru. marketing harus menginputkan data secara lengkap dan benar dan menyimpannya. Sistem akan memeriksa data yang dimasukan dan menyimpannya ke database (Gambar 3).

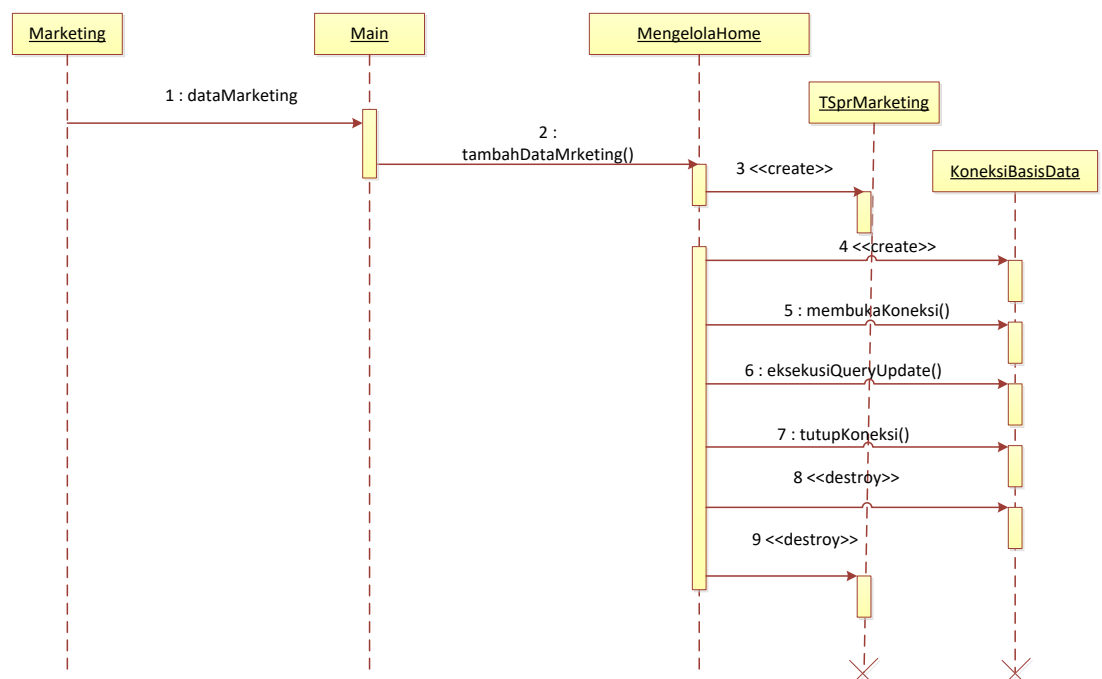

Gambar 3.Diagram Sequence Tambah Marketing

Marketingakan mengakses halaman home dan memilih menu client, kemudian sistem akan menampilkan halaman pengaturan marketing. Marketing dapat menghapus akun marketing dengan memilih menu akun marketing dan pada halaman ini akan ditampilkan daftar akun marketing. Marketing memilih menu hapus dan sistem akan meminta persetujuan dalam penghapusan akun marketing. Apabila marketing setuju maka sistem akan menghapus dan menampilkan pesan bahwa data telah dihapus (Gambar 4).

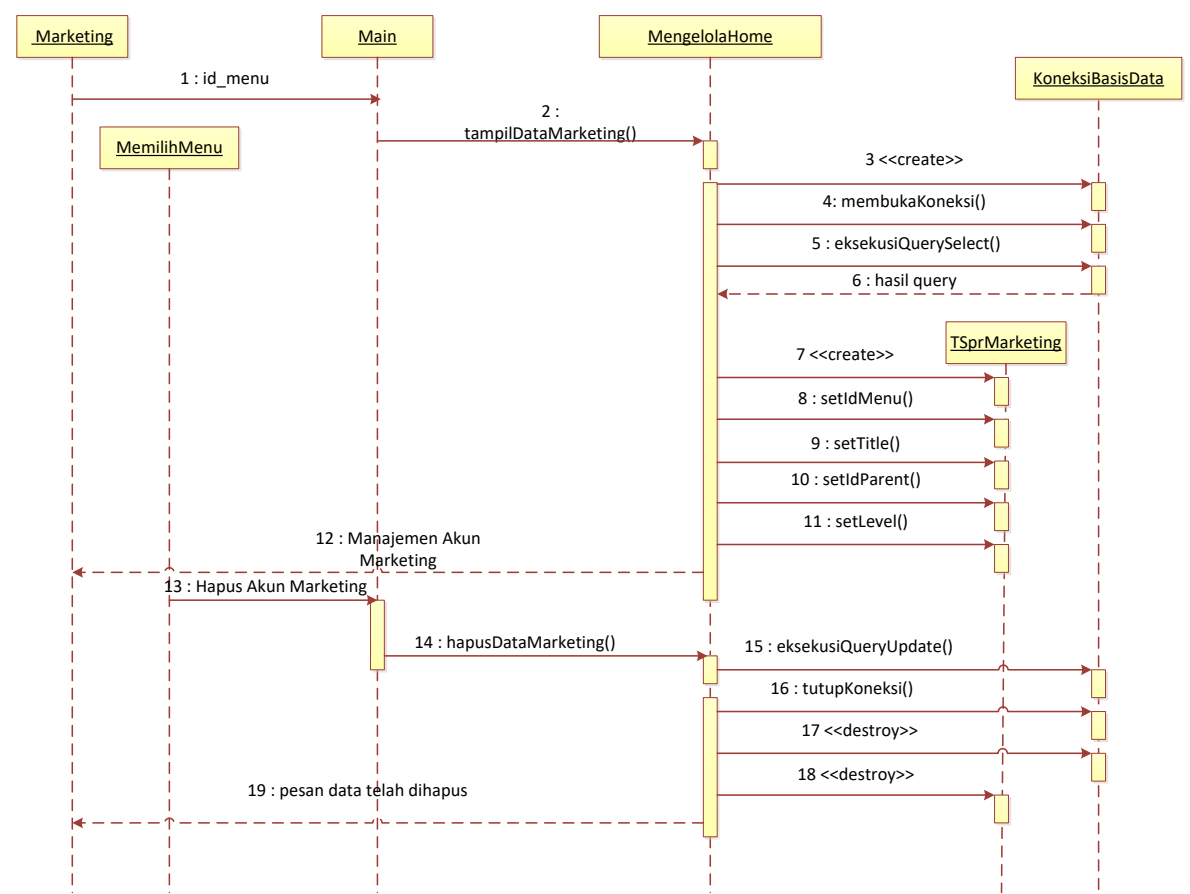

Gambar 4.Diagram Sequence Hapus Marketing

Activity diagram yaitu diagram yang menggambar sebuah proses bisnis dan memperlihatkan aliran dari suatu aktivitas ke aktivitas lainnya dalam sistem yang ada. Activity 
diagram diatas menggambarkan mengenai arus loginmarketing pada web mobile PT.Papasari Pontianak. Pertama marketing memilih menu login dan sistem akan menampilkan form login. Kemudian marketing menginputkan username, password dengan benar ke form login. Setelah itu sistem akan melakukan validasi terhadap data yang telah diinput, jika data valid maka sistem akan menampilkan halaman marketing dan apabila tidak maka akan kembali ke halaman form login (Gambar 5).

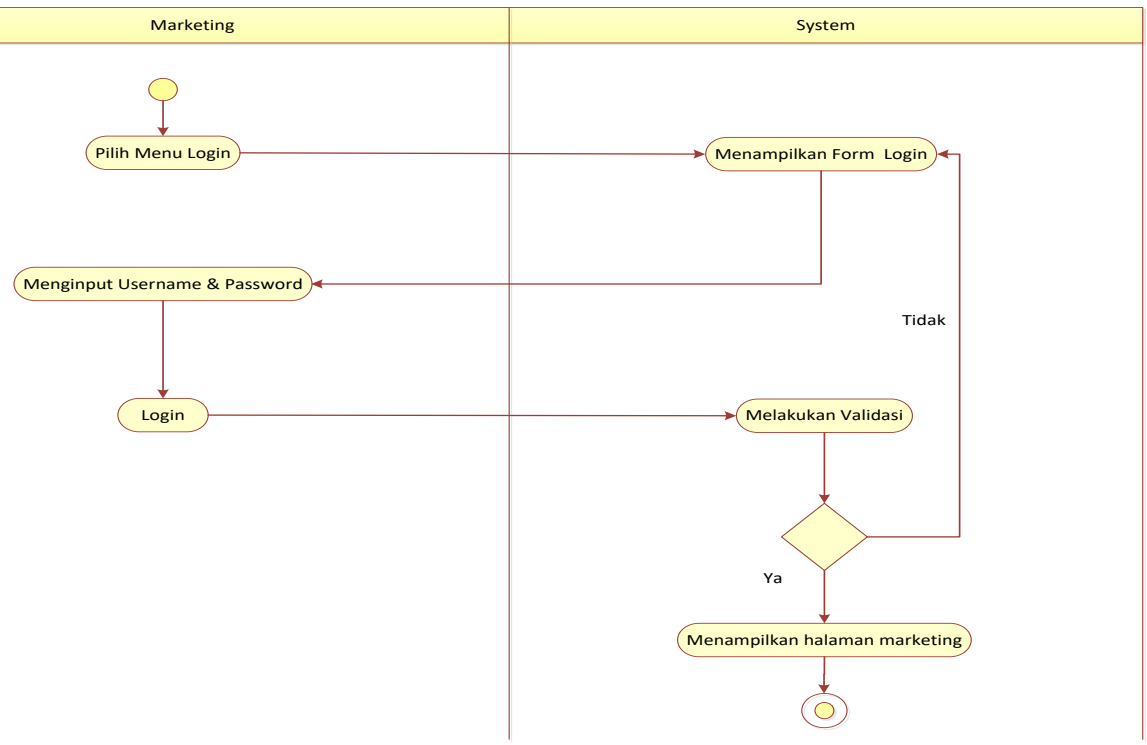

Gambar 5.Diagram Activity Login Marketing

Activity diagrampada gambar 6 menggambarkan arus mengenai mengelola produk pada web mobile PT.Papasari Pontianak. Pertama marketing melakukan login terlebih dahulu dan sistem akan menampilkan halaman marketing. Kemudian marketing memilih menu produk dan sistem akan menampilkan halaman produk yang tersedia menu tambah produk, edit produk dan hapus produk. Apabila memilih menu tambah produk maka sistem akan menampilkan form tambah produk, jika memilih menu edit produk maka sistem akan menampilkan form edit produk dan kalau memilih menu hapus produk maka sistem langsung menghapus produk tersebut. Apabila semua kegiatan yang telah dilakukan di halaman produk sudah selesai, maka sistem akan menyimpan data tersebut ke database.

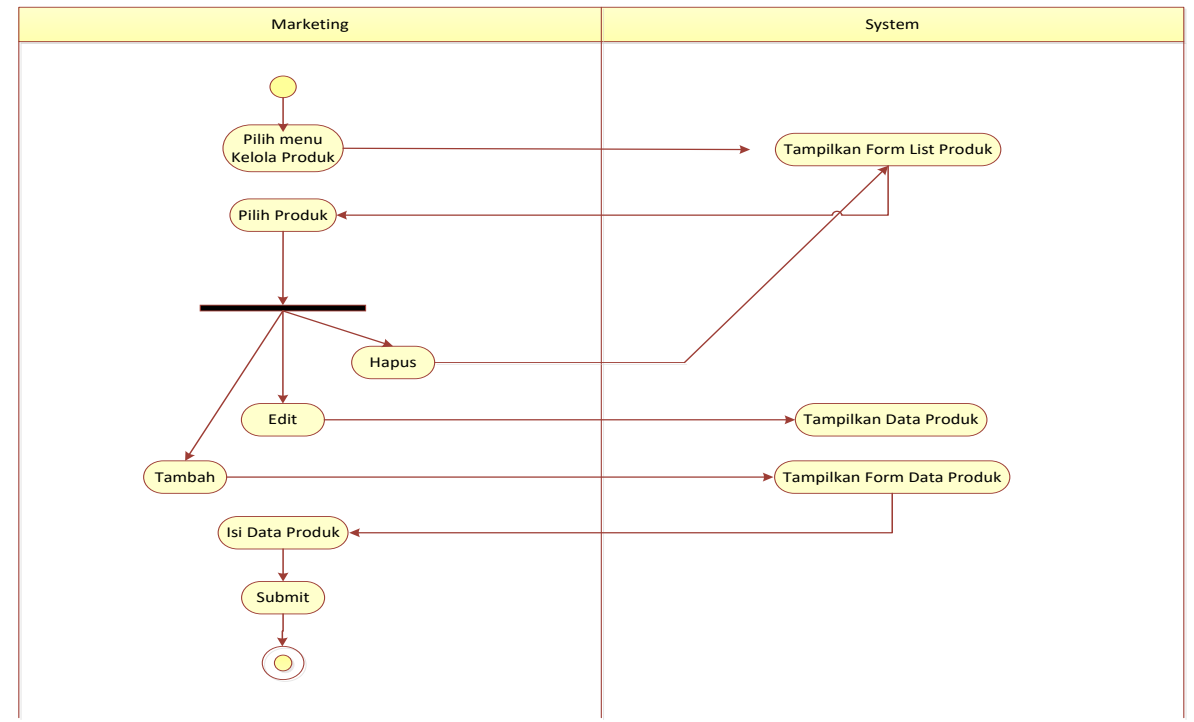

Gambar 6.Diagram Activity Mengelola Produk 
Activity diagram pada gambar 5.23 diatas menggambarkan arus mengenai mengelola kategori produk pada web mobile PT.Papasari Pontianak. Pertama marketing melakukan login terlebih dahulu dan sistem akan menampilkan halaman marketing. Kemudian marketing memilih menu kategori dan sistem akan menampilkan halaman kategori produk. Apabila marketing memilih tambah kategori produk maka sistem akan menampilkan form tambah kategori produk, jika memilih edit kategori produk maka sistem akan menampilkan form edit kategori produk dan kalau memilih menu hapus kategori produk maka sistem langsung menghapus kategori produk tersebut. Apabila semua kegiatan yang telah dilakukan di halaman kategori produk sudah selesai, maka sistem akan menyimpan data tersebut ke database.

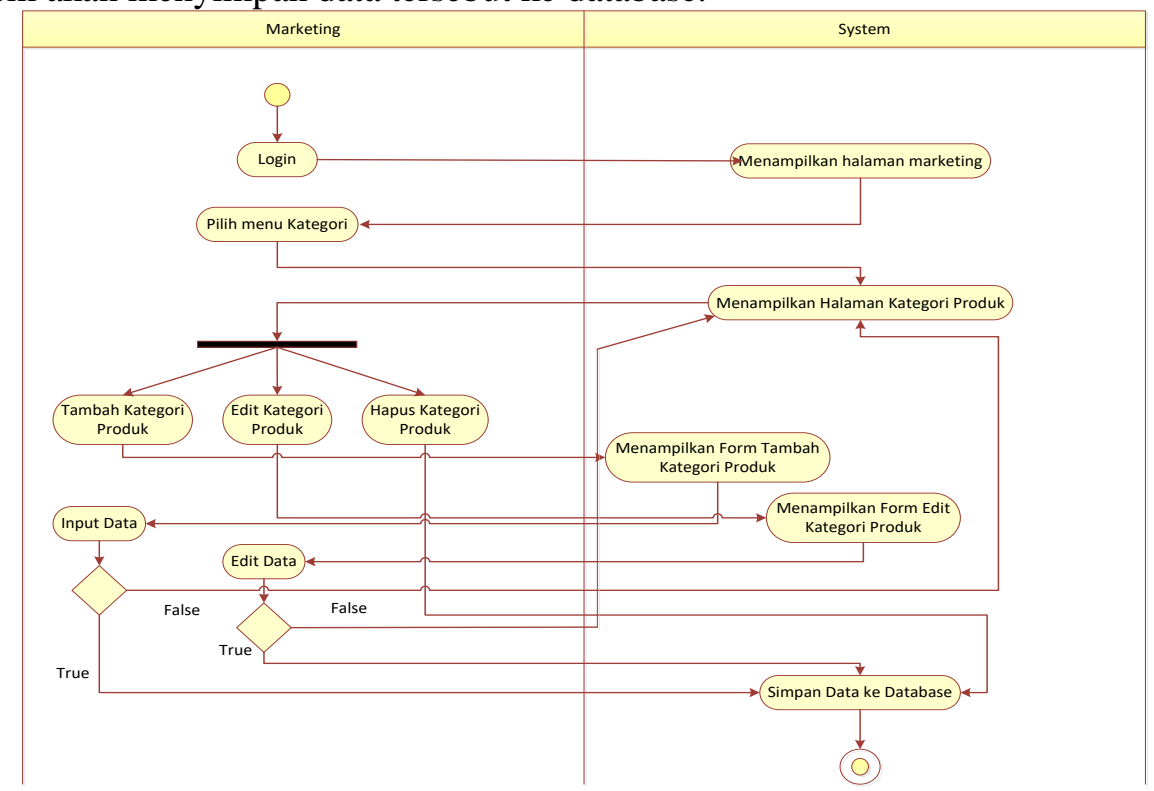

Gambar 7.Activity Diagram Mengelola Kategori Produk

Class Diagram digunakan untuk menggambarkan beberapa class serta paket yang digunakan pada sistem/perangkat lunak beserta relasi-relasi yang ada. Class diagram pada web mobile PT.Papasari Pontianak yang terdiri dari beberapa kelas, yaitu Marketing, Login, Salesman, Produk, PemesananProduk, Laporan, dan Database. Kelas Login mempunyai relasi composition dengan kelas Marketing dan Salesman, dimana mempunyai relationship one-to-one atau one-tomany dengan kedua tabel tersebut. Kelas Produk mempunyai relasi dependency dengan kelas Login dan kelas Database.Kelas PemesananProduk mempunyai relasi dependency dengan kelas Login dan kelas Database, dimana mempunyai relationship one-to-one dengan kedua tabel tersebut.Kelas Laporan mempunyai relasi dependency dengan kelas Login dan kelas Database, dimana mempunyai relationship one-to-one dengan kedua tabel tersebut (Gambar 8). 


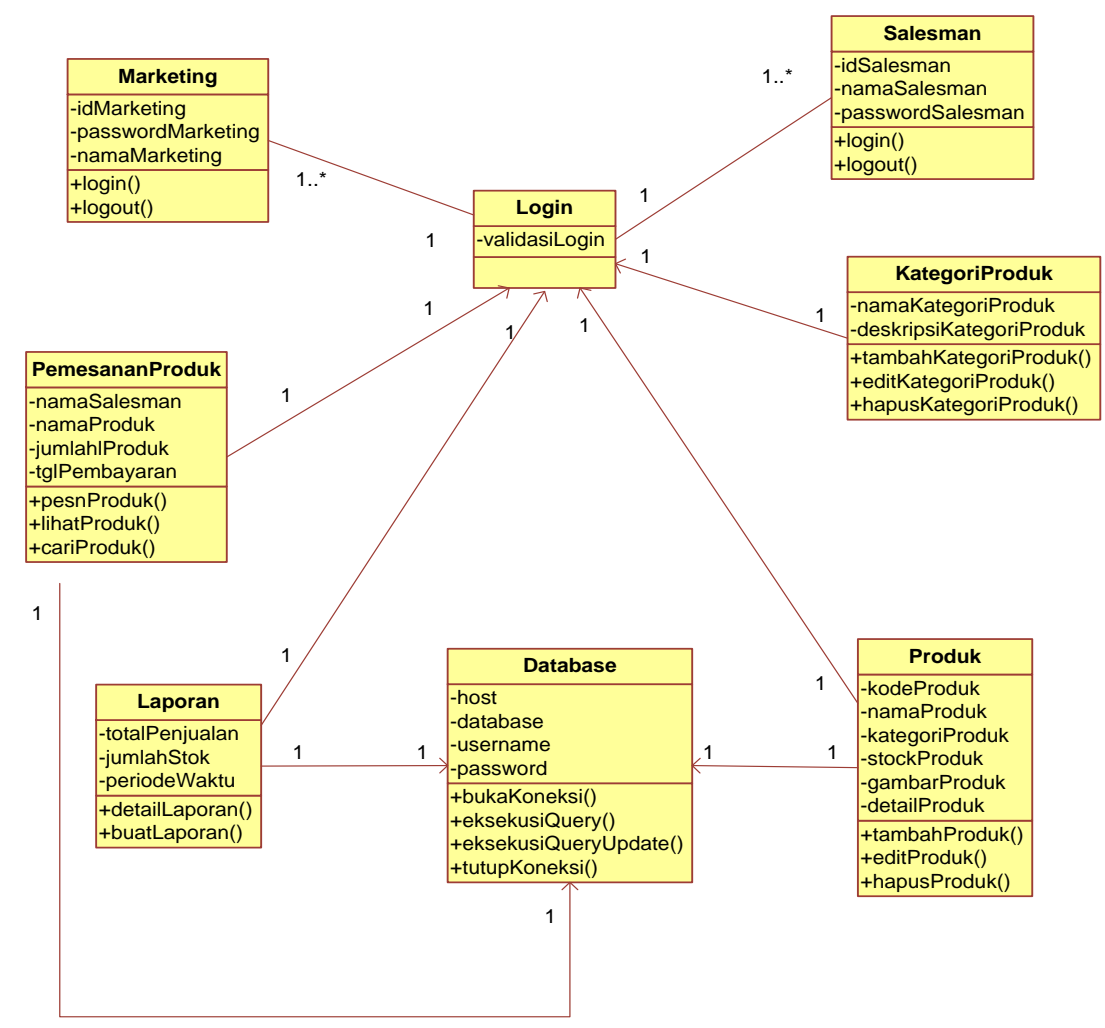

Gambar 8.Class Diagram Aplikasi Kinerja Karyawan

Proses coding pada XP diawali dengan membangun serangkaian modul program aplikasi kinerja salesman yang akan diuji dan di implementasikan pada PT. Papasari Pontianak. Dalam XP diperkenalkan istilah pair programming dimana proses penulisan program dilakukan dengan saling bekerjasama dalam membuat modul program, dengan ini akan didapat real-time problem solving dan real-time quality assurance. Tahapan coding merupakan tahapan dari pembuatan sistem yang sesungguhnya.Dalam pengimplementasian sistem yang dibuat, digunakan sebuah aplikasi berbasis mobile, dengan bahasa pemograman menggunakan bahasa pemrograman PHP (Hypertext Preprocessor) dengan menggunakan framework jquery mobile.Berikut ini adalah implementasi dari rancangan sistem pengolahan data debitur BII Maybank cabang Pontianak secara keseluruhan. 


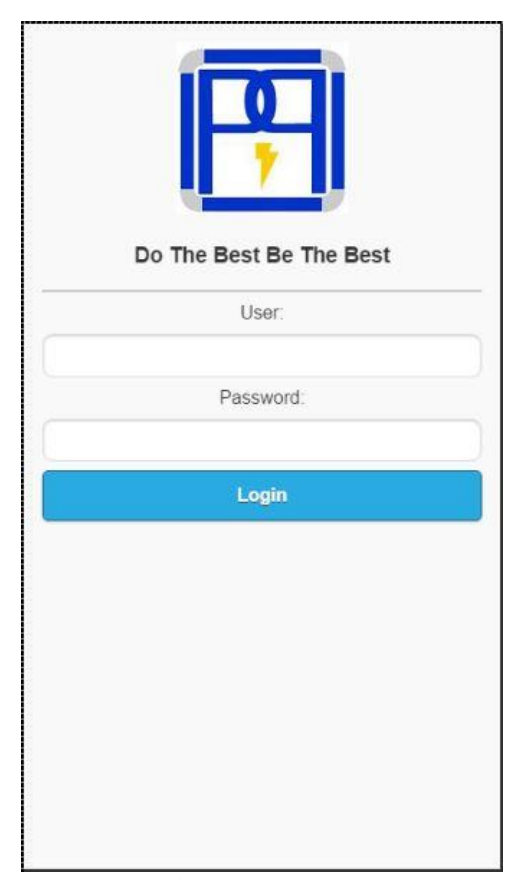

Gambar 9. Implementasi Rancangan Form Login Salesman

Gambar 9 menunjukkan bahwa pada loginsalesman, pada awalnya salesmanakan memasukkan username danpassword. Sistem akan mengakses database untuk mengecek valid tidaknya username danpassword yang dimasukkan. Jika tidak valid maka sistem akan memberikan perintah bahwa salesman gagal login, jika valid maka sistem akan memasuki halaman admin.

Halaman utama aplikasi kinerjasalesmanPT.Papasari Pontianak terdiri dari gambar produk, menu home, cart, dan back, sedangkan halaman menu salesmanterdapat menu home, notification, user, client, invoice, indent, report, dan logout. Halaman kategori produk pada web mobile berisikan kategori produk yang tersedia (Gambar 10).

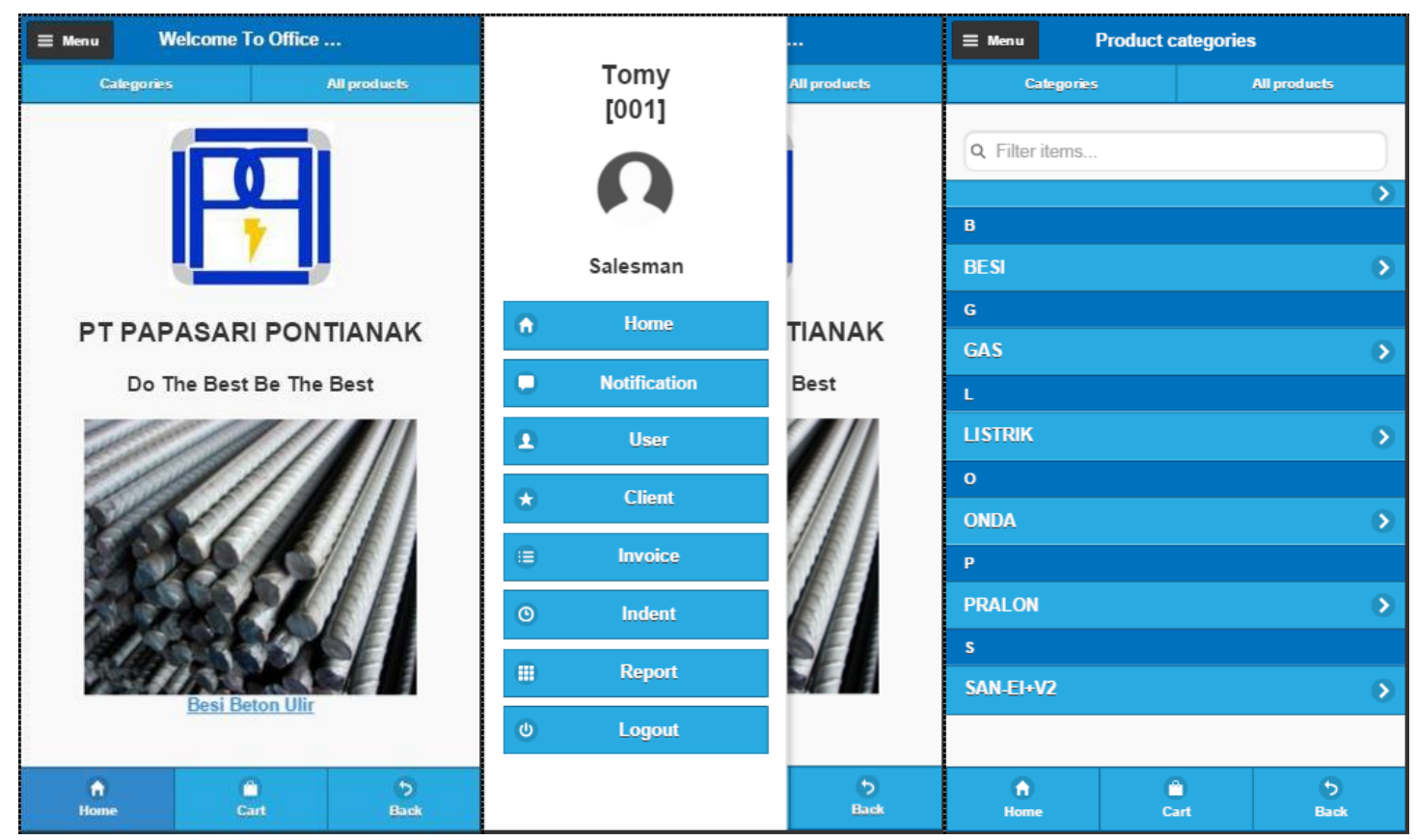

Gambar 10.Halaman Utama Salesman Pada Web Mobile PT.Papasari Pontianak 
Marketing dapat melakukan tambah produk, edit produk dan hapus produk, apabila marketing ingin menambah produk maka marketing dapat mengisi form yang telah ada, maka data produk baru tersebut akan masuk ke dalam database PT.Papasari Pontianak. Apabila marketing ingin mengedit produk maka marketing dapat memilih produk yang ada dan mengubah data produk tersebut,maka perubahan data produk tersebut akan disimpan ke dalam database. Apabila marketing ingin menghapus produk maka marketing memilih produk yang ingin dihapus dan menekan tombol hapus. Apabila setuju untuk menghapus data produk maka sistem akan menghapus data produk tersebut dari database dan apabila tidak maka marketing akan diarahkan kembali ke halaman produk (Gambar 11).

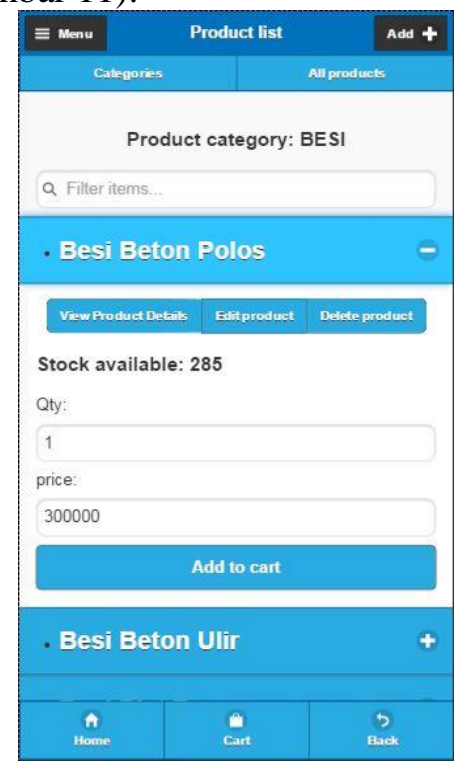

Gambar 11.Implementasi Rancangan Kelola Produk

Pada saat ingin memesan barang maka pada awalnya memilih produk yang ingin dipesan kemudian menekan tombol keranjang, kemudian akan menampilkan form keranjang belanja yang berisikan orderan-orderan yang telah diinputkan. Pilih check out setelah selesai memilih produk dan kemudian akan muncul pemberitahuan dinotofication dan selanjutnya diproses oleh marketing. Pemberitahuan orderan yang sudah diproses atau belum pada ditampilkan pada halaman notifikasi salesman.(Gambar 12).

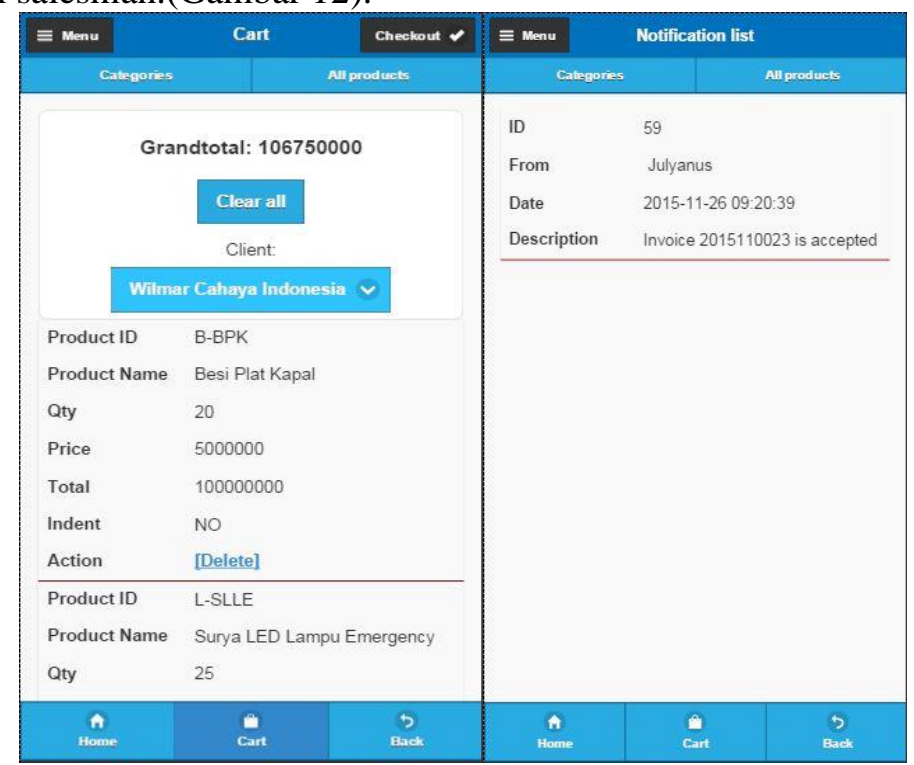

Gambar 12.Implementasi Rancangan Pemesanan Produk 
Tahap terakhir dalam metode extreme programming adalah dengan melakukan pengujian atau testing. Pengujian aplikasi kinerja salesman dilakukan dengan cara memilih sejumlah modul dengan berbagai tipe data untuk memastikan bahawa program ini hanya menerima input dengan tipe data yang benar. Pemilihan modul yang akan digunakan dalam pengujian program aplikasi kinerja salesman ini dilakukan dengan metode black-box. Metode pengujian black- box memfokuskan pada keperluan fungsional dari software, maka dari itu pengujian black-box memungkinkan pengembang software untuk membuat himpunan kondisi input yang akan melatih seluruh syarat-syarat fungsional suatu program. Pengujian black-box telah dilakukan pada form pengisian data debitur dimana hasil pengujiannya dapat dilihat pada tabel 1,2, dan 3 berikut ini.

Tabel 1. Hasil Pengujian Form Login

\begin{tabular}{|c|c|c|c|}
\hline NO & $\begin{array}{l}\text { PENGUJIAN YANG } \\
\text { DILAKUKAN }\end{array}$ & HASIL & $\begin{array}{l}\text { KESESUAIAN } \\
\text { DENGAN } \\
\text { HARAPAN }\end{array}$ \\
\hline 1. & $\begin{array}{l}\text { Login tanpa mengisi } \\
\text { email dan password }\end{array}$ & $\begin{array}{l}\text { Muncul pesan "Email tidak boleh } \\
\text { kosong" kembali ke form login }\end{array}$ & Sesuai \\
\hline 2. & $\begin{array}{l}\text { Login tanpa mengisi } \\
\text { username atau password }\end{array}$ & $\begin{array}{l}\text { Muncul pesan "Email tidak boleh } \\
\text { kosong" kembali ke form login }\end{array}$ & Sesuai \\
\hline 3. & $\begin{array}{l}\text { Login dengan email } \\
\text { tidak valid }\end{array}$ & $\begin{array}{l}\text { Muncul pesan "Silakan masukan } \\
\text { email yang valid" kembali ke } \\
\text { form login }\end{array}$ & Sesuai \\
\hline 4. & $\begin{array}{l}\text { Login dengan password } \\
\text { yang salah }\end{array}$ & $\begin{array}{l}\text { Muncul pesan "Password yang } \\
\text { digunakan salah atau tidak sesuai" } \\
\text { kembali ke form login }\end{array}$ & Sesuai \\
\hline
\end{tabular}

Tabel 2. Hasil Pengujian Form Menu Utama

\begin{tabular}{|c|c|c|c|}
\hline NO & $\begin{array}{l}\text { PENGUJIAN YANG } \\
\text { DILAKUKAN }\end{array}$ & HASIL & $\begin{array}{l}\text { KESESUAIAN } \\
\text { DENGAN } \\
\text { HARAPAN }\end{array}$ \\
\hline 1. & Menekan menu Home & $\begin{array}{l}\text { Menampilkan halaman beranda } \\
\text { web mobile PT.Papasari } \\
\text { Pontianak }\end{array}$ & Sesuai \\
\hline 2. & Menekan menu Notifications & $\begin{array}{l}\text { Menampilkan halaman } \\
\text { notification }\end{array}$ & Sesuai \\
\hline 3. & Menekan menu User & Menampilkan halaman user & Sesuai \\
\hline 4. & Menekan menu tentang Client & Menampilkan halaman client & Sesuai \\
\hline 5. & Menekan menu Invoice & Menampilkan halaman invoice & Sesuai \\
\hline 6. & Menekan menu Indent & Menampilkan list indent & Sesuai \\
\hline 7. & Menekan menu Report & Menampilkan report & Sesuai \\
\hline 8. & Menekan menu Logout & Keluar dari web mobile & Sesuai \\
\hline
\end{tabular}

Tabel 3.Hasil Pengujian Form Kategori

\begin{tabular}{|c|c|c|c|}
\hline NO & $\begin{array}{l}\text { PENGUJIAN YANG } \\
\text { DILAKUKAN }\end{array}$ & HASIL & $\begin{array}{c}\text { KESESUAIAN } \\
\text { DENGAN HARAPAN }\end{array}$ \\
\hline
\end{tabular}




\begin{tabular}{llll}
\hline 1. & $\begin{array}{l}\text { Menekan menu kategory } \\
\text { besi }\end{array}$ & Menampilkan produk besi & Sesuai \\
\hline 2. & $\begin{array}{l}\text { Menekan menu kategory } \\
\text { gas }\end{array}$ & Menampilkan produk gas & Sesuai \\
\hline 3. & $\begin{array}{l}\text { Menekan menu kategory } \\
\text { listrik }\end{array}$ & Menampilkan produk listrik & Sesuai \\
\hline 4. & $\begin{array}{l}\text { Menekan menu kategory } \\
\text { onda }\end{array}$ & Menampilkan produk onda & Sesuai \\
\hline 5. & $\begin{array}{l}\text { Menekan menu kategory } \\
\text { pralon }\end{array}$ & Menampilkan produk pralon & Sesuai \\
\hline $6 . \quad \begin{array}{l}\text { Menekan menu kategory } \\
\text { sanei }\end{array}$ & Menampilkan produk sanei & \\
\hline
\end{tabular}

\section{PENUTUP}

Hasil penelitian ini adalah menghasilkan suatu sistem web mobile untuk meningkatkan kinerja salesman pada PT. Papasari Pontianak yang berguna untuk memperluas jangkauan pasar penjualan. Pengembangan web mobile PT. Papasari Pontianak ini berfungsi sebagai media untuk membantu meningkatkan kinerja salesman dan mampu menyediakan informasi tentang stok produk yang dijual secara up to date dan menampilkan setiap laporan penjualan. Untuk realisasi penerapannya membutuhkan sisi keamanan yang harus tetap diperhatikan dan disarankan penggunaan secured page pada halaman administrator (https), antisipasi terhadap PHP injection, floading, dan ancaman keamanan lainnya terhadap yang mungkin menyerang sistem web mobile PT. Papasari Pontianak.

\section{SARAN}

Tampilan aplikasi yang dibangun masih sederhana dan dapat dikembangkan lagi agar tampilan menjadi lebih baik dan lebih menarik serta meningkatkan customer relationship management yang lebih baik lagi dari yang telah ada di PT. Papasari Pontianak.

\section{DAFTAR PUSTAKA}

[1]. Alfawaer, Z. M., Awni, M., Al-Zoubi, S., 2011, Mobile e-ticketing reservation system for Amman International Stadium in Jordan, International Journal of Academic Research, No. 1, Vol. 3, Hal. 848-852.

[2]. Gat, 2016, Pengembangan Sistem Reservasi Hotel Berbasis Mobile dengan Framework JQuery Mobile, CITEC Journal, Vol. 3, No. 1, Hal. 26-36

[ 3]. Sugiyono, 2011, "Metode Penelitian Kuantitatif kualitatif dan R\&D”, Alfabeta, Bandung.

[4]. Pressman, Roger S., 2010, Software Engineering A Practitioner's Approach, 7th Edition. McGraw Hill International Edition, USA. 


\section{Pedoman Penulisan Makalah SISFOTENIKA}

1. Topik yang akan dipublikasikan oleh Jurnal - Jurnal SISFOTENIKA berhubungan dengan teknologi informasi, komunikasi dan komputer yang berbentuk kumpulan/akumulasi pengetahuan baru, pengamatan empirik atau hasil penelitian, dan pengembangan gagasan atau usulan baru

2. Naskah ditulis dalam bahasa Indonesia baku atau bahasa Inggris, belum pernah dipublikasikan serta bebas dari unsur plagiat. Naskah dilengkapi surat pernyataan tertulis dikirim melalui OJS masing - masing Jurnal anggota CORIS (Cooperation Computer Research Inter University).

3. Redaksi berhak menolak naskah yang tidak memenuhi kriteria/persyaratan teknis, mengadakan perubahan susunan naskah, memperbaiki bahasa dan berkonsultasi dengan penulis sebelum naskah dimuat.

4. Naskah diketik dengan komputer menggunakan Microsoft Word, di atas kertas ukuran $21 \mathrm{~cm} \mathrm{x}$ $29,7 \mathrm{~cm}$ (A4), margin atas bawah kanan kiri $3 \mathrm{~cm}$, spasi 1, huruf Times New Roman ukuran font untuk judul artikel adalah 18 point, dan font pada isi makalah 11 point. Naskah ditulis dengan layout 1 kolom.

5. Jumlah halaman berkisar antara 10 sampai 14 halaman, dan jumlah gambar tidak boleh melebihi $30 \%$ dari seluruh tulisan

6. Judul makalah maksimal 12 kata dalam bahasa Indonesia atau 10 kata dalam Bahasa Inggris. Judul harus mencerminkan dengan tepat masalah yang dibahas di makalah, dengan menggunakan kata-kata yang ringkas, lugas, tepat, jelas dan mengandung unsur-unsur yang akan dibahas.

7. Nama penulis ditulis di bawah judul sebelum abstrak tanpa disertai gelar akademik atau gelar lain apapun. Instansi penulisa dituliskan Program Studi, Jurusan, Fakultas, dan nama Perguruan Tinggi penulis bernaung dan alamat email untuk korespondensi dengan ukuran 11 point bold.

8. Sistematika penulisan naskah, terdiri dari:

a. Abstrak dan kata kunci

Abstrak ditulis dalam bahasa Indonesia dan bahasa Inggris dengan panjang masing-masing 150 - 200 kata dan dicetak miring dengan Times New Roman 11 point, diketik dengan jarak 1 spasi. Abstrak disusun dengan kalimat-kalimat ringkas, jelas, runtut, sistematis, dapat menggambarkan apa serta mengapa penelitian dikerjakan, bagaimana dikerjakan, dan apa hasil penting yang dicapai dari penelitian.

b. Pendahuluan

Pendahuluan ditulis dengan Times New Roman 11 point. Pendahuluan menguraikan:

1) latar belakang permasalahan yang diselesaikan, dan isu-isu yang terkait dengan masalah yang diselesaikan.

2) tinjauan pustaka yang memuat uraian sistematis tentang informasi hasil-hasil penelitian yang pernah dilakukan oleh peneliti-peneliti sebelumnya yang relevan dengan penelitian yang akan dilakukan. Bagian ini memuat kelebihan dan kelemahan yang mungkin ada pada penelitian-penelitian sebelumnya yang dapat dijadikan argumen bahwa penelitian yang akan dikerjakan ini bersifat menyempurnakan atau mengembangkan penelitian terdahulu.

3) landasan teori berupa rangkuman teori-teori yang diambil dari pustaka yang mendukung penelitian, serta memuat penjelasan tentang konsep dan prinsip dasar yang diperlukan untuk pemecahan permasalahan. Landasan teori dapat berbentuk uraian kualitatif, model matematis, atau tools yang langsung berkaitan dengan permasalahan yang diteliti. 
c. Metode Penelitian

Bagian ini memuat penjelasan secara lengkap dan terinci tentang langkah-langkah yang dilakukan dalam penelitian ini. Selain itu, langkah penelitian juga perlu ditunjukkan dalam bentuk diagram alir langkah penelitian atau framework secara lengkap dan terinci termasuk di dalamnya tercermin algoritma, rule, pemodelan-pemodelan, desain, dan lain-lain yang terkait dengan aspek perancangan sistem.

d. Hasil dan Pembahasan

Bagian Hasil dan Pembahasan merupakan bagian yang memuat semua temuan ilmiah yang diperoleh sebagai data hasil penelitian. Bagian ini diharapkan memberikan penjelasan ilmiah yang secara logis dapat menerangkan alasan diperolehnya hasil-hasil tersebut yang dideskripsikan secara jelas, lengkap, terinci, terpadu, sistematis, serta berkesinambungan.

Pemakalah menyusun secara sistematis disertai argumentasi yang rasional tentang informasi ilmiah yang diperoleh dalam penelitian, terutama informasi yang relevan dengan masalah penelitian. Pembahasan terhadap hasil penelitian yang diperoleh dapat disajikan dalam bentuk uraian teoritik, baik secara kualitatif maupun kuantitatif. Dalam pelaksanaannya, bagian ini dapat digunakan untuk memperbandingkan hasil-hasil penelitian yang diperoleh dalam penelitian yang sedang dilakukan terhadap hasil-hasil penelitian yang dilaporkan oleh peneliti terdahulu yang diacu pada penelitian ini. Secara ilmiah, hasil penelitian yang diperoleh dalam penelitian dapat berupa temuan baru atau perbaikan, penegasan, atau penolakan interpretasi suatu fenomena ilmiah dari peneliti sebelumnya

Untuk memperjelas penyajian, hasil penelitian disajikan secara cermat agar mudah dipahami, misalnya dapat ditunjukkan dalam bentuk tabel, kurva, grafik, gambar, foto, atau bentuk lainnya sesuai keperluan secara lengkap dan jelas. Perlu diusahakan agar saat membaca hasil penelitian dalam format tersebut, pembaca tidak perlu mencari informasi terkait dari uraian dalam pembahasan. Akhir dari bagian ini memuat keterangan tentang kelebihan dan kelemahan sistem, yang dideskripsikan secara terinci.

Tabel dan gambar harus diberi identitas yang berupa nomor urut dan judul tabel atau gambar yang sesuai dengan isi tabel atau gambar, serta dilengkapi dengan sumber kutipan.

Judul tabel ditulis dalam Times New Roman 11 point, ditempatkan di atas tabel, tanpa diakhiri tanda titik. Tabel tidak boleh dipenggal, kecuali kalau tidak mungkin diketik dalam satu halaman. Pada halaman lanjutan tabel dicantumkan nomor tabel dan ditulis kata Lanjutan tanpa judul. Bagan, grafik, peta, foto, semuanya disebut gambar. Judul gambar dalam Times New Roman 11 point, tepat di bawah gambar, tanpa diakhiri oleh tanda titik. Keterangan gambar dituliskan pada tempat yang kosong pada halaman yang sama. Skala dan satuan pada grafik harus dibuat sejelas mungkin. Setiap tabel dan gambar harus dirujuk dalam makalah.

Persamaan harus diberi nomor urut pada bagian sebelah kanan.

e. Kesimpulan dan Saran

1) Kesimpulan

Saran merupakan pernyataan singkat, jelas, dan tepat tentang apa yang diperoleh, memuat keunggulan dan kelemahan, dapat dibuktikan, serta terkait langsung dengan tujuan penelitian. Uraian pada bagian ini harus merupakan pernyataan yang pernah dianalisis/dibahas pada bagian sebelumnya, bukan pernyataan yang sama sekali baru dan tidak pernah dibahas pada bagian sebelumnya, serta merupakan jawaban atas permasalahan yang dirumuskan. Bagian ini tidak perlu ada uraian penjelasan lagi.

2) Saran

Saran memuat berbagai usulan atau pendapat yang sebaiknya dikaitkan oleh penelitian sejenis. Saran dibuat berdasarkan kelemahan, pengalaman, kesulitan, kesalahan, temuan baru yang belum diteliti dan berbagai kemungkinan arah penelitian selanjutnya. 


\section{f. Daftar Pustaka}

Pustaka Buku yang digunakan harus maksimal 10 tahun terakhir dari waktu penyusunan artikel dan untuk pustaka Jurnal/Proceeding maksimal 5 tahun terakhir. Setiap penulis wajib merujuk 1 artikel yang telah dipublish oleh oleh anggota CORIS. Adapun anggota CORIS adalah:

$\begin{array}{lll}\text { No } & \text { Nama PTS } & \text { Nama Jurnal } \\ 1 & \text { Univ Potensi Utama Medan } & \text { CSRID } \\ 2 & \text { Univ Klabat Manado } & \text { Jurnal Ilmu Komputer } \\ 3 & \text { Univ Dian Nuswantoro Semarang } & \text { JAIS } \\ 4 & \text { STMIK Pontianak } & \text { Sisfotenika } \\ 5 & \text { STMIK Dipanegara } & \text { Jusiti } \\ 6 & \text { STMIK Tasikmalaya } & \text { Voice of Informatics } \\ 7 & \text { STIKOM Bali } & \text { Eksplora Informatika } \\ 8 & \text { STMIK Raharja } & \text { CCIT } \\ 9 & \text { STMIK AMIKOM Yogyakarta } & \text { CITEC Journal }\end{array}$

Daftar pustaka disusun menurut urutan kemunculan rujukan. Urutan dimulai dengan penulisan nama penulis, tahun, judul, penerbit, dan kota terbit. Penulisan nama penulis adalah nama keluarga (nama belakang) diikuti nama kecil (nama depan). Untuk kutipan dari internet berisi nama penulis, judul artikel, alamat website, dan tanggal akses. Daftar Pustaka hanya memuat pustaka yang benar-benar diacu dalam makalah ditulis Times New Roman 11 point, dan disusun sbb:

1. Urutan Daftar Pustaka berdasarkan berdasarkan urutan kemunculan rujukan.

2. Daftar Pustaka hanya memuat pustaka yang benar-benar diacu dalam makalah ditulis Times New Roman 11 point, dan disusun sbb:

1) Urutan Daftar Pustaka berdasarkan berdasarkan urutan kemunculan rujukan.

2) Tulisan untuk suatu sumber pustaka diketik satu spasi. Jarak di antara sumber pustaka tetap dua spasi.

3) Sumber refernsi dari Internet harus berasal dari artikel ilmiah-resmi.

4) Setiap pustaka ditulis menurut:

a) Buku: nama pengarang, tahun penerbitan, judul, edisi (jika perlu), jilid (jika perlu), nama penerbit, kota penerbit

b) Majalah/Jurnal Ilmiah/Prosiding: nama penulis, tahun penerbitan, judul, nama majalah/jurnal ilmiah/prosiding, edisi (jika perlu), nama penerbit, kota penerbit

c) Laporan Penelitian: nama peneliti, tahun, judul, jenis penelitian, nama lembaga, kota

d) Internet: nama penulis, tanggal akses, judul artikel, alamat URL secara lengkap. Publikasi di web selain e-book, e-journal, dan e-proceeding tidak diperbolehkan untuk dijadikan rujukan penelitian ilmiah.

g. Biodata Penulis

Pada bagian akhir paper memuat biodata penulis yang mencakup nama lengkap, tempat tanggal lahir, alamat koresponden (rumah/kantor dan email), tahun lulus dan bidang ilmu untuk S1, S2 atau S3, spesialisasi dan minat keilmuan serta hal-hal lain yang dianggap perlu dicantumkan. 


\title{
Template Jurnal SISFOTENIKA \\ ISSN : 2087 - 7897 \\ ISSN (ONLINE) : $2460-5344$
}

\section{Judul Naskah Publikasi Maksimum 12 Kata Dalam Bahasa Indonesia atau 10 Kata Dalam Bahasa Inggris}

\author{
Penulis pertama $^{* 1}$, Penulis kedua $^{2}$, Penulis ketiga ${ }^{3}$ \\ 1,2,3 Instansi Penulis meliputi Program Studi Jurusan Fakultas Nama Perguruan Tinggi \\ E-mail: ${ }^{* 1} \underline{\operatorname{xxxx} @ \mathbf{x x x x . x x x}}, \underline{{ }^{2} \mathrm{Xxx} @ \operatorname{xxxx} . x x x},{ }^{3} \underline{\operatorname{xxx} @ \mathrm{Xxxx} . \mathrm{xxx}}$
}

\begin{abstract}
Abstrak
Abstrak terdiri dari 150-200 kata berbahasa Indonesia dicetak miring dengan Times New Roman 11point. Abstrak harus jelas, deskriptif dan harus memberikan gambaran singkat masalah yang diteliti. Abstrak meliputi alasan pemilihan topik atau pentingnya topik penelitian, metode penelitian dan ringkasan hasil. Abstrak harus diakhiri dengan komentar tentang pentingnya hasil atau kesimpulan singkat.
\end{abstract}

Kata Kunci-3-5 kata kunci dalam bahasa Indonesia

\section{Abstract}

Abstract should contain at least 150 - 200 words, written in English in italics with Times New Roman 11 point. Abstract should be clear, descriptive, and should provide a brief overview of the problem studied. Abstract topics include reasons for the selection or the importance of research topics, research methods and a summary of the results. Abstract should end with a comment about the importance of the results or conclusions brief.

Keywords-3-5 kata kunci dalam bahasa Inggris

\section{PENDAHULUAN}

Pendahuluan menguraikan latar belakang permasalahan yang diselesaikan, isu-isu yang terkait dengan masalah yang diselesaikan, ulasan penelitan yang pernah dilakukan sebelumnya oleh peneliti lain yang relevan dengan penelitian yang dilakukan.

\section{Metode PENELITIAN}

Metode Penelitian (bisa meliputi analisa, arsitektur, metode yang dipakai untuk menyelesaikan masalah, implementasi), dalam bahasan ini penulis bisa menguraikan bagaimana penelitian tersebut akan dilakukan.

\subsection{Tahapan Review}

Harap mengirimkan naskah anda secara elektronik untuk direview sebagai attachment email. Ketika anda mengirimkan dokumen naskah versi awal dalam format word.doc satu kolom, termasuk gambar dan tabel. 
ISSN: $2087-7897$

ISSN (ONLINE) : 2460 - 5344

\subsubsection{Gambar dan Tabel}

Semua tabel dan gambar yang Anda masukkan dalam dokumen harus disesuaikan dengan urutan 1 kolom atau ukuran penuh satu kertas, agar memudahkan bagi reviewer untuk mencermati makna gambar. Gambar dan tabel yang dimuat harus dirujuk dan diberikan penjelasannya dalam naskah.

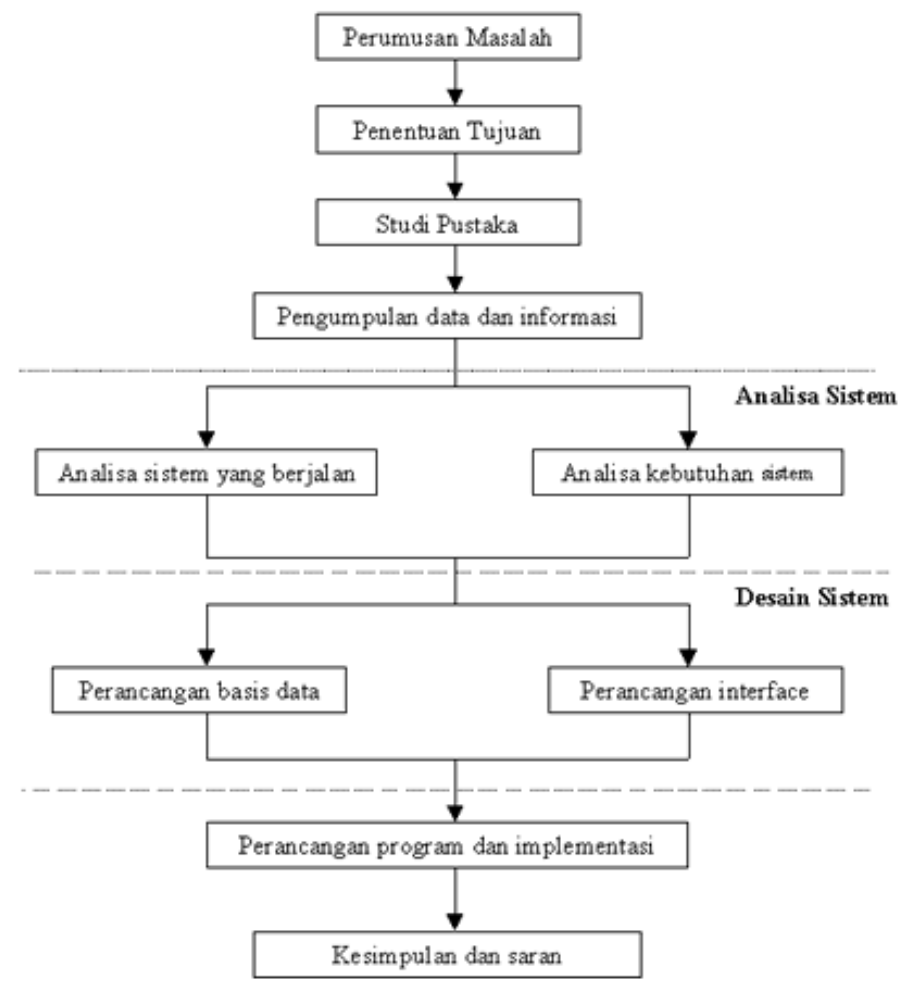

Gambar 1. Alur Penelitian

\subsection{Formulir Copyright}

Formulir copyright harus disertakan pada pengiriman naskah akhir. Anda bisa meminta versi .pdf, atau .doc via email ke indoceiss@ gmail.com

\subsubsection{Rumus Matematika}

Jika anda menggunakan Ms. Word, gunakan persamaan Microsoft Equation Editor atau MathType, ditulis di tengah, dan diberi nomor persamaan mulai dari (1), (2) dst.

$$
\text { ? }(\text { 回, 目 })=(0 \leq 0 \leq 0-1,0 \leq 0 \leq 0-1)
$$

\subsubsection{Pengacuan Pustaka}

Pengacuan pustaka dilakukan dengan menggunakan penomoran sesuai urutan munculnya pustaka tersebut, misal sitasi buku [1], sitasi jurnal ilmiah [2]. Sitasi kepustakaan harus ada dalam Daftar Pustaka dan Daftar Pustaka harus ada sitasinya dalam naskah. Pustaka yang disitasi pertama kali pada naskah, harus ada pada daftar pustaka nomor satu, pustaka yang disitasi kedua yang muncul dalam naskah muncul sebagai daftar pustaka urutan kedua, berikut seterusnya. 
ISSN: $2087-7897$

ISSN (ONLINE) : 2460 - 5344

Setiap Penulis wajib merujuk 1 artikel yang telah dipublish jurnal-jurnal anggota CORIS. Berikut daftar anggota CORIS:

$\begin{array}{ll}\text { No } & \text { Nama PTS } \\ 1 & \text { Univ Potensi Utama Medan } \\ 2 & \text { Univ Klabat Manado } \\ 3 & \text { Univ Dian Nuswantoro Semarang } \\ 4 & \text { STMIK Pontianak } \\ 5 & \text { STMIK Dipanegara } \\ 6 & \text { STMIK Tasikmalaya } \\ 7 & \text { STIKOM Bali } \\ 8 & \text { STMIK Raharja } \\ 9 & \text { STMIK AMIKOM Yogyakarta }\end{array}$

\author{
Nama Jurnal \\ CSRID \\ Jurnal Ilmu Komputer \\ JAIS \\ Sisfotenika \\ Jusiti \\ Voice of Informatics \\ Eksplora Informatika \\ CCIT \\ CITEC Journal
}

Pustaka Buku yang digunakan harus maksimal 10 tahun terakhir dari penyusunan artikel dan untuk pustaka Jurnal/Proceeding maksimal 5 tahun terakhir.

\section{HASIL DAN PEMBAHASAN}

Pembahasan terhadap hasil penelitian dan pengujian yang diperoleh disajikan dalam bentuk uraian teoritik, baik secara kualitatif maupun kuantitatif. Hasil percobaan sebaiknya ditampilkan dalam berupa grafik ataupun tabel. Untuk grafik dapat mengikuti format untuk diagram dan gambar..

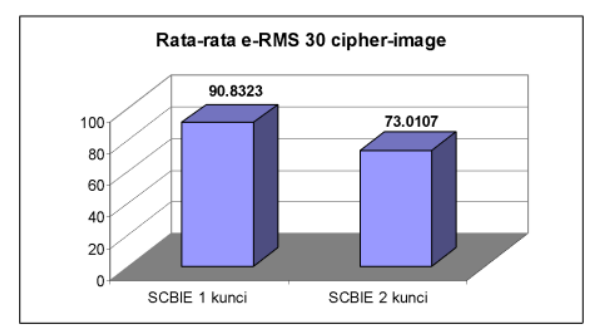

Gambar 2. Grafik perbandingan

Tabel 1. Perbandingan Algoritma A dan Algoritma B

\begin{tabular}{|c|c|c|c|}
\hline Memori & Ketelitian & $\begin{array}{c}\text { Waktu } \\
\text { Proses }\end{array}$ & Algoritma \\
\hline $200 \mathrm{~KB}$ & $98 \%$ & $120 \mathrm{~ms}$ & A \\
\hline $415 \mathrm{~KB}$ & $95 \%$ & $105 \mathrm{~ms}$ & $\mathrm{~B}$ \\
\hline
\end{tabular}

\section{KESIMPULAN}

Kesimpulan harus mengindikasi secara jelas hasil-hasil yang diperoleh, kelebihan dan kekurangannya, serta kemungkinan pengembangan selanjutnya.

Kesimpulan dapat berupa paragraf, namun sebaiknya berbentuk point-point dengan menggunakan numbering. 
ISSN: $2087-7897$

ISSN (ONLINE) : $2460-5344$

\section{SARAN}

Dalam bahasan ini memuat saran untuk menutup kekurangan penelitian. Tidak memuat saran-saran selain untuk penelitian yang lebih lanjut.

\section{UCAPAN TERIMA KASIH} penelitian ini.

Penulis mengucapkan terima kasih kepada xxx yang telah memberi dukungan terhadap

\section{DAFTAR PUSTAKA}

- Buku dengan urutan penulisan: Penulis, tahun, judul buku (harus ditulis miring) volume (jika ada), edisi (jika ada), nama penerbit dan kota penerbit.

[1] Castleman, K. R., 2004, Digital Image Processing, Vol. 1, Ed.2, Prentice Hall, New Jersey.

- Buku Terjemahan dengan urutan penulisan: Penulis asli (nama depan, tengah. (disingkat), belakang. (disingkat)), tahun buku terjemahan, judul bukuterjemahan (harus ditulis miring), volume (jika ada), edisi (jika ada), (diterjemahkan oleh: nama penerjemah), nama penerbit terjemahan dan kota penerbit terjemahan.

[2] Gonzales, R., P. 2004, Digital Image Processing (Pemrosesan Citra Digital), Vol. 1, Ed.2, diterjemahkan oleh Handayani, S., Andri Offset, Yogyakarta.

- Artikel dalam Buku dengan urutan penulisan: Penulis artikel, tahun, judul artikel (harus ditulis miring), nama editor, judul buku (harus ditulis miring), volume (jika ada), edisi (jika ada), nama penerbit dan kota penerbit.

[3] Wyatt, J. C, danSpiegelhalter, D., 1991, Field Trials of Medical Decision-Aids: Potential Problems and Solutions, Clayton, P. (ed.): Proc. 15th Symposium on Computer Applications in Medical Care, Vol 1, Ed. 2, McGraw Hill Inc, New York. 
-Pustaka dalam bentuk artikel dalam majalah ilmiah:

Urutan penulisan: Penulis, tahun, judul artikel, nama majalah (harus ditulis miring sebagai singkatan resminya), nomor, volume dan halaman.

[4] Yusoff, M, Rahman, S., A., Mutalib, S., and Mohammed, A., 2006, Diagnosing Application Development for Skin Disease Using Backpropagation Neural Network Technique, Journal of Information Technology, vol 18, hal 152-159.

\section{- Pustaka dalam bentuk artikel dalam seminar ilmiah:}

Artikel dalam prosiding seminar dengan urutan penulisan: Penulis, tahun, judul artikel, Judul prosiding Seminar (harus ditulis miring), kota seminar, tanggal seminar.

[5] Wyatt, J. C, Spiegelhalter, D, 2008, Field Trials of Medical Decision-Aids: PotentialProblems and Solutions, Proceeding of 15th Symposium on ComputerApplications in Medical Care, Washington, May 3.

- Pustaka dalam bentuk Skripsi/Tesis/Disertasi dengan urutan penulisan: Penulis, tahun, judul skripsi, Skipsi/Tesis/Disertasi (harus ditulis miring), nama fakultas/ program pasca sarjana, universitas, dan kota.

[6]Prasetya, E., 2006, Case Based Reasoning untuk mengidentifikasi kerusakan bangunan, Tesis, Program Pasca Sarjana Ilmu Komputer, Univ. Gadjah Mada, Yogyakarta.

\section{-Pustaka dalam bentuk Laporan Penelitian:}

Urutan penulisan: Peneliti, tahun, judul laporan penelitian, nama laporan penelitian (harus ditulis miring), nama proyek penelitian, nama institusi, dan kota.

[7]Ivan, A.H., 2005, Desain target optimal, Laporan Penelitian Hibah Bersaing, Proyek Multitahun, Dikti, Jakarta.

Pustaka dalam bentuk artikel dalam internet (tidak diperkenankan melakukan sitasi artikel dari internet yang tidak ada nama penulisnya):

- Artikel majalah ilmiah versi cetakan dengan urutan penulisan: Penulis, tahun, judul artikel, nama majalah (harus ditulis miring sebagai singkatan resminya), nomor, volume dan halaman.

[8] Wallace, V. P., Bamber,J. C. dan Crawford, D. C. 2000. Classification of reflectance spectra from pigmented skin lesions, a comparison of multivariate discriminate analysis and artificial neural network. Journal Physical Medical Biology, No.45, Vol.3, 2859-2871.

- Artikel majalah ilmiah versi online dengan urutan penulisan:Penulis, tahun, judul artikel, nama majalah ((harus ditulis miring sebagai singkatan resminya), nomor, volume, halaman dan alamat website.

[9] Xavier Pi-Sunyer, F., Becker, C., Bouchard, R.A., Carleton, G. A., Colditz, W., Dietz, J., Foreyt, R. Garrison, S., Grundy, B. C., 1998, Clinical Guidlines on the identification, evaluation, and treatment of overweight and obesity in adults, Journal of National Institutes of Health, No.3, Vol.4, 123-130, http://journals.lww.com/acsmmsse/Abstract/1998/11001/paper_treatment_of_obesity.pdf, diakses tanggal 23 Februari 2016.

- Artikel umum dengan urutan penulisan: Penulis, tahun, judul artikel, alamat website (harus ditulis miring), diakses tanggal ... 
[10] Borglet, C, 2003, Finding Asscociation Rules with Apriori Algorithm, http://www.fuzzy.cs.uniagdeburgde/ borglet/apriori.pdf, diakses tgl 23 Februari 2007.

Daftar Pustaka hanya memuat semua pustaka yang diacu pada naskah tulisan, bukan sekedar pustaka yang dibaca. Pustaka ditulis urut kemunculan pengacuan di naskah, bukan urut abjad penulis.

[1] Castleman, Kenneth R., 2004, Digital Image Processing, Vol. 1, Ed.2, Prentice Hall, New Jersey.

[2] Gonzales, R., P. 2004, Digital Image Processing (Pemrosesan Citra Digital), Vol. 1, Ed.2, diterjemahkan oleh Handayani, S., Andri Offset, Yogyakarta.

[3] Wyatt, J. C, danSpiegelhalter, D., 1991, Field Trials of Medical Decision-Aids: PotentialProblems and Solutions, Clayton, P. (ed.): Proc. 15th Symposium on ComputerApplications in Medical Care, Vol 1, Ed. 2, McGraw Hill Inc, New York.

[4] Yusoff, M, Rahman, S., A., Mutalib, S., and Mohammed, A., 2006, Diagnosing Application Development for Skin Disease Using Backpropagation Neural Network Technique, Journal of Information Technology, vol 18, hal 152-159.

[5] Wyatt, J. C, Spiegelhalter, D, 2008, Field Trials of Medical Decision-Aids: PotentialProblems and Solutions, Proceeding of 15th Symposium on ComputerApplications in Medical Care, Washington, May 3.

[6] Prasetya, E., 2006, Case Based Reasoning untuk mengidentifikasi kerusakan bangunan, Tesis, Program Pasca Sarjana Ilmu Komputer, Univ. Gadjah Mada, Yogyakarta.

[7] Ivan, A.H., 2005, Desain target optimal, Laporan Penelitian Hibah Bersaing,Proyek Multitahun, Dikti, Jakarta.

[8] Wallace, V. P., Bamber,J. C. dan Crawford, D. C. 2000. Classification of reflectance spectra from pigmented skin lesions, a comparison of multivariate discriminate analysis and artificial neural network. Journal Physical Medical Biology, No.45, Vol.3, 2859-2871.

[9] Xavier Pi-Sunyer, F., Becker, C., Bouchard, R.A., Carleton, G. A., Colditz, W., Dietz, J., Foreyt, R. Garrison, S., Grundy, B. C., 1998, Clinical Guidlines on the identification, evaluation, and treatment of overweight and obesity in adults, Journal of National Institutes of Health, No.3, Vol.4, 123-130, http://journals.lww.com/acsmmsse/Abstract/1998/11001/paper_treatment_of_obesity.pdf.

[10] Borglet, C, 2003, Finding Asscociation Rules with Apriori Algorithm, http://www.fuzzy.cs.uniagdeburgde/ borglet/apriori.pdf, diakses tgl 23 Februari 2007. 


\title{
FORM PENILAIAN REVIEWER SISFOTENIKA
}

\begin{abstract}
Judul :
Penulis
\end{abstract}

\begin{tabular}{|c|c|c|c|c|c|}
\hline NO & UNSUR & KETERANGAN & MAKS & NILAI KETERANGAN & MASUKAN \\
\hline \multirow{3}{*}{1} & \multirow{3}{*}{$\begin{array}{l}\text { Keefektifan Judul } \\
\text { Artikel }\end{array}$} & \multirow{3}{*}{$\begin{array}{l}\text { Maksimal } 12 \text { (dua belas) } \\
\text { kata dalam Bahasa } \\
\text { Indonesia atau } 10 \\
\text { (sepuluh) kata dalam } \\
\text { Bahasa Inggris }\end{array}$} & \multirow{3}{*}{2} & $\begin{array}{l}\text { a. Tidak lugas dan tidak } \\
\text { ringkas }(0)\end{array}$ & \\
\hline & & & & $\begin{array}{l}\text { b. Kurang lugas dan } \\
\text { kurang ringkas (1) }\end{array}$ & \\
\hline & & & & c. Ringkas dan lugas (2) & \\
\hline \multirow{3}{*}{2} & \multirow{3}{*}{$\begin{array}{l}\text { Pencantuman Nama } \\
\text { Penulis dan } \\
\text { Lembaga Penulis }\end{array}$} & & \multirow{3}{*}{1} & $\begin{array}{l}\text { a. Tidak lengkap dan } \\
\text { tidak konsisten }(0)\end{array}$ & \\
\hline & & & & $\begin{array}{l}\text { b. Lengkap tetapi tidak } \\
\text { konsisten }(0,5)\end{array}$ & \\
\hline & & & & $\begin{array}{l}\text { c. Lengkap dan konsisten } \\
\text { (1) }\end{array}$ & \\
\hline \multirow{3}{*}{3} & \multirow{3}{*}{ Abstrak } & \multirow{3}{*}{$\begin{array}{l}\text { Dalam Bahasa Indonesia } \\
\text { dan Bahasa Inggris yang } \\
\text { baik, jumlah 150-200 } \\
\text { kata. Isi terdiri dari latar } \\
\text { belakang, metode, hasil, } \\
\text { dan kesimpulan. Isi } \\
\text { tertuang dengan kalimat } \\
\text { yang jelas. }\end{array}$} & \multirow{3}{*}{2} & $\begin{array}{l}\text { a. Tidak dalam Bahasa } \\
\text { Indonesia dan Bahasa } \\
\text { Inggris (0) }\end{array}$ & \\
\hline & & & & $\begin{array}{l}\text { b. Abstrak kurang jelas } \\
\text { dan ringkas, atau hanya } \\
\text { dalam Bahasa Inggris, } \\
\text { atau dalam Bahasa } \\
\text { Indonesia saja (1) }\end{array}$ & \\
\hline & & & & $\begin{array}{l}\text { c. Abstrak yang jelas dan } \\
\text { ringkas dalam Bahasa } \\
\text { Indonesia dan Bahasa } \\
\text { Inggris (2) }\end{array}$ & \\
\hline \multirow{3}{*}{4} & \multirow{3}{*}{ Kata Kunci } & \multirow{3}{*}{$\begin{array}{l}\text { Maksimal } 5 \text { kata kunci } \\
\text { terpenting dalam paper }\end{array}$} & \multirow{3}{*}{1} & a. Tidak ada (0) & \\
\hline & & & & $\begin{array}{l}\text { b. Ada tetapi kurang } \\
\text { mencerminkan konsep } \\
\text { penting dalam artikel } \\
(0,5)\end{array}$ & \\
\hline & & & & $\begin{array}{l}\text { c. Ada dan } \\
\text { mencerminkan konsep } \\
\text { penting dalam artikel (1) }\end{array}$ & \\
\hline \multirow{3}{*}{5} & \multirow{3}{*}{$\begin{array}{l}\text { Sistematika } \\
\text { Pembaban }\end{array}$} & \multirow{3}{*}{$\begin{array}{l}\text { Terdiri dari pendahuluan, } \\
\text { tinjauan pustaka, metode } \\
\text { penelitian, hasil dan } \\
\text { pembahasan, kesimpulan } \\
\text { dan saran, daftar pustaka }\end{array}$} & \multirow{3}{*}{1} & a. Tidak lengkap (0) & \\
\hline & & & & $\begin{array}{l}\text { b. Lengkap tetapi tidak } \\
\text { sesuai sisetm }(0,5)\end{array}$ & \\
\hline & & & & $\begin{array}{l}\text { c. Lengkap dan } \\
\text { bersistem (1) }\end{array}$ & \\
\hline 6 & Pemanfaatan & Pemanfaatan Instrumen & 1 & a. Tak termanfaatkan $(0)$ & \\
\hline
\end{tabular}




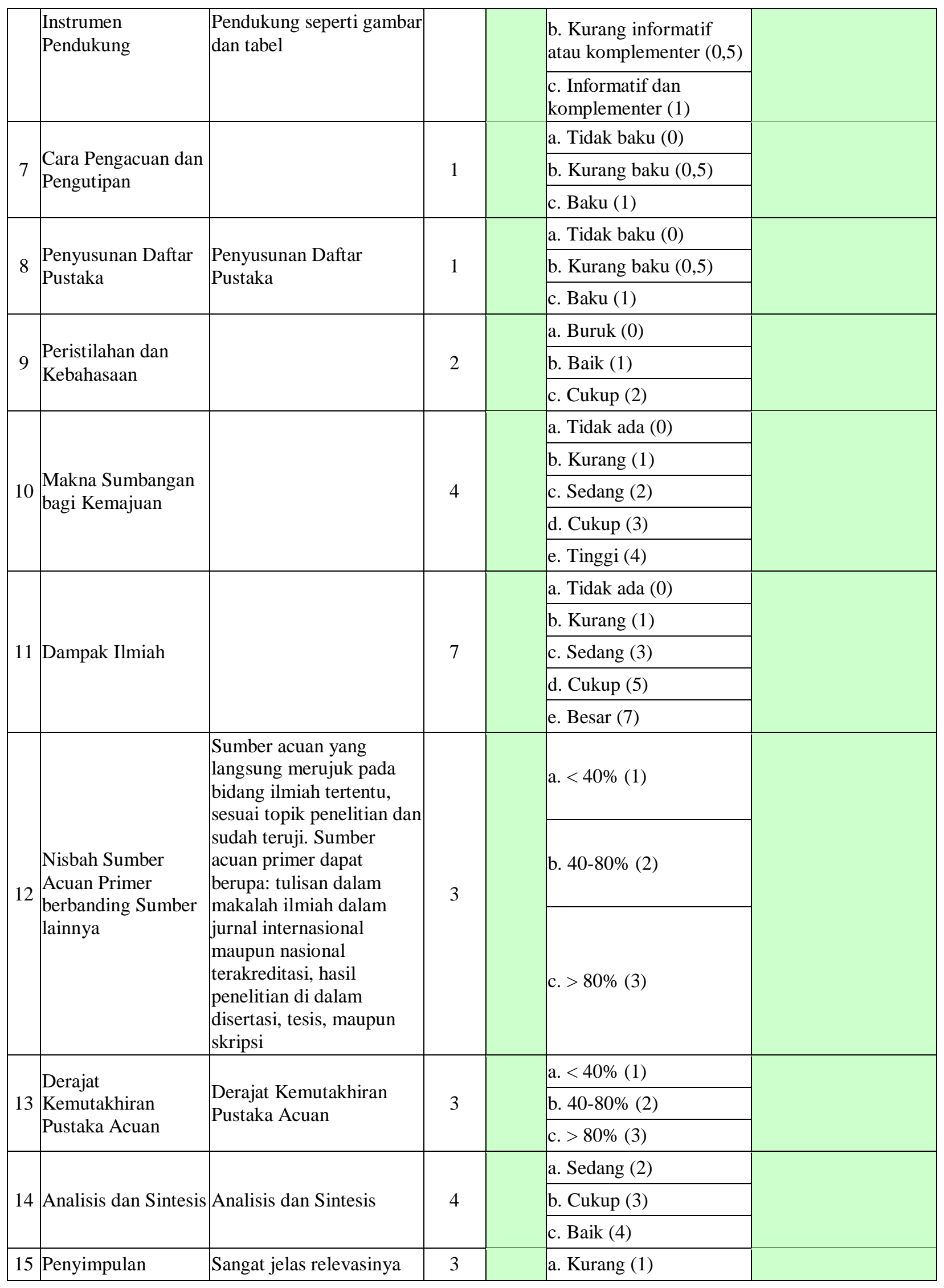




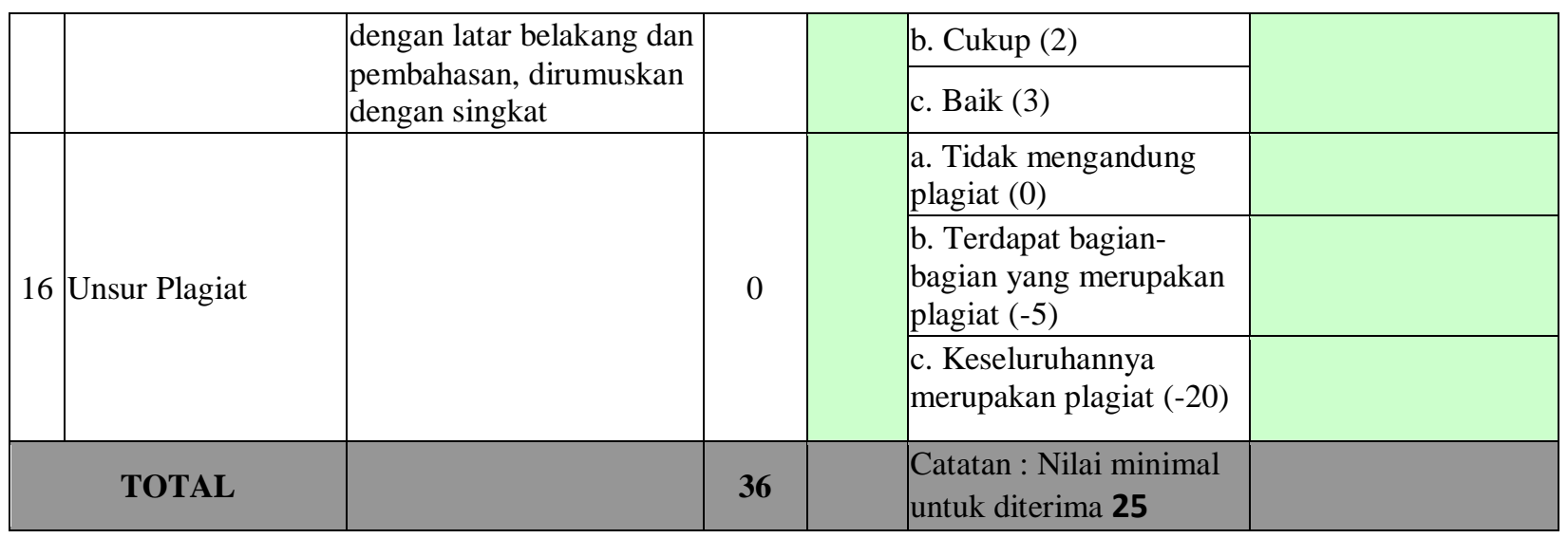

\section{Catatan:}

\section{Plagiat :}

Reviewer,

(Nama Reviewer) 
Nama

Unversitas/Instansi

Alamat Pengiriman

Telp. /Fax/Email

\section{FORMULIR BERLANGGANAN \\ JURNAL SISFOTENIKA \\ STMIK PONTIANAK}

Telah mengirimkan uang sebesar Rp.

Rincian

Rp.

[Sisfotenika Edisi]

Rp. [Biaya Kirim]

$8<$

Pilihan Berlangganan :

$\square 2$ [dua] edisi - Akademisi

Rp. $\left.100.000,-{ }^{*}\right)$

$\square 2$ [dua] edisi - Umum (Non Akademisi)

Rp. $\left.120.000,,^{*}\right)$

*) Biaya berlangganan belum termasuk biaya kirim sebesar Rp. 20.000,- / 2 edisi

Untuk berlangganan, kirimkan formulir ini beserta bukti transfer pembayaran:

a. Via surat ke alamat:

\section{Redaksi Jurnal SISFOTENIKA}

STMIK Pontianak

Jl. Merdeka No. 372 Pontianak, Kalimantan Barat

Telp. 0561-735555

b. Via fax ke 0561-737777

c. Via Email ke alamat : Sisfotenika@stmikpontianak.ac.id

Untuk informasi lebih lanjut dapat menghubungi telepon 0561-735555 atau mengirimkan email ke sisfotenika@stmikpontianak.ac.id atau sisfotenika@gmail.com Pembayaran dapat dilakukan melalui transfer rekening:

\section{Bank}

No. Rek.

$\mathbf{a} / \mathbf{n}$.

Berita :Sisfotenika (Biaya Berlangganan) 


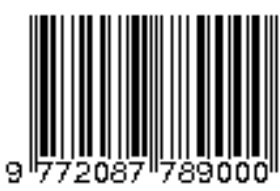

